Kilby (eds.). 1999 Citrus and deciduous fruit and nut research report. College Agr. Ser. P-117. Univ. Ariz., Tucson.

McCloskey, W.B., G.C. Wright, and K.C. Taylor. 1996. Managing vegetation on the orchard floor in flood-irrigated Arizona citrus groves, p. 58-77. In: G. Wright (ed.). 1996 Citrus research report. College Agr. Ser. P-105. Univ. Ariz., Tucson.

Metcalf, R.L. and R.A. Metcalf. 1993. Destructive and useful insects: Their habits and control. $5^{\text {th }}$ ed. McGraw Hill, New York.

Merwin, I.A. and W.C. Stiles. 1994. Orchard groundcover management impacts on apple tree growth and yield, and nutrient availability and uptake. J. Amer. Soc. Hort. Sci. 119:209-215.

Merwin, I.A., W.C. Stiles, and H.M. van Es. 1994. Orchard groundcover management impacts on soil physical properties. J. Amer. Soc. Hort. Sci. 119:216-222.

Mitchell, H.L. 1972. Micro determination of nitrogen in plant tissues. J. AOAC. 55: $1-3$.

Page, A.L., R.H. Miller, and D.R. Keeny. 1982. Methods of soil analysis. Part 2. Chemical and microbiological properties, p. 574. In: Agronomy (9). 2nd ed. Amer. Soc. Agron., Soil Sci. Soc. Amer., Madison, Wis.

Parker, M.L., J. Hull, and R.L. Perry. 1993. Orchard floor management affects peach rooting. J. Amer. Soc. Hort. Sci. 118:714-718.

Perkin-Elmer. 1982. Analysis of plant tissue: Wet digestion. Perkin-Elmer Agr. Appl. AY5:1-3. Perkin-Elmer Anal. Instr., Shelton, Conn.

Roberson, E.B., S. Sarig, and M.K. Firestone. 1991. Cover crop management of polysaccharide-mediated aggregation in an orchard soil. Soil Sci. Soc. Amer. J. 55: 734-739.

Ross, S.M., J.R. King, R.C. Izaurralde, and J.T. Donovan. 2001. Weed suppression by seven clover species. Agron. J. 93: 820-827.
Ross, M.A. and C.A. Lembi. 1999. Applied weed science. $2^{\text {nd }}$ ed. Prentice Hall, Upper Saddle River, N.J.

Sainju, U.M. and B.P. Singh. 1997. Winter cover crops for sustainable agricultural systems: influence on soil properties, water quality, and crop yields. HortScience 32 : 21-28.

Singh, M., D.P.H. Tucker, and S.H. Futch. 1990. Multiple applications of preemergence herbicide tank mixtures in young citrus groves. Proc. Fla. State Hort. Soc. 103:16-21.

Smith, M.W., M.E. Wolf, B.S. Cheary, and B.L. Carroll. 2001. Allelopathy of bermudagrass, tall fescue, redroot pigweed and cutleaf evening primrose on pecan. HortScience 36:1047-1048.

Syvertson, J.P. and J.J. Lloyd. 1994. Citrus, p. 65-100. In: B. Schaffer and P.C. Anderson (eds.). Handbook of environmental physiology of fruit crops. vol. 2. Subtropical and tropical crops. CRC Press Inc., Boca Raton, Fla.

Teasdale, J.R. 1996. Contribution of cover crops to weed management in sustainable agricultural systems. J. Prod. Agr. 9: 475-479.

Tedders, W.L. 1983. Insect management in deciduous orchard ecosystems: habitat manipulation. Environ. Mgt. 7:29-34.

Tucker, D.P.H., C.G. Erickson, and K.T. Morgan. 1997. Middles management methods in citrus affect soil moisture retention and vegetation species. Proc. Fla. State Hort. Soc. 110:39-43.

Walsh, B.D., S. Salmins, D.J. Buszard, and A.F. MacKenzie. 1996. Impact of soil management systems on organic dwarf apple orchards and soil aggregate stability, bulk density, temperature and water content. Can. J. Soil Sci. 76:203-209.

Wutscher, H.K. and P.F. Smith. 1993. Citrus, p. 165-170. In: W.F. Bennett (ed.). Nutrient deficiencies and toxicities in crop plants. APS Press, St. Paul, Minn.

\section{Variety, Shading, and Growth Stage Effects on Pigment Concentrations in Lettuce Grown under Contrasting Temperature Regimens}

\author{
Matthew D. Kleinhenz, ${ }^{1,3}$ \\ Darla G. French, ${ }^{2}$ \\ Aparna Gazula, ${ }^{1}$ and \\ Joseph C. Scheerens ${ }^{1}$
}

Additional INDEX WORDS. Lactuca sativa, light intensity, anthocyanin, antioxidant, chlorophyll, 'Galactic', 'Green Vision', greenhouse, leaf color, 'New Red Fire', quality, 'Rolina', stress

Summary. Shading effects on chlorophyll a (ChlA), chlorophyll b (ChlB) and anthocyanin (Antho) concentrations were examined at three developmental stages in four varieties of lettuce (Lactuca sativa) grown under contrasting temperature regimens in the greenhouse. Seedlings were transplanted to pots and grown at $\mathbf{3 0}$

${ }^{\circ} \mathrm{C}\left(86.0^{\circ} \mathrm{F}\right) \mathrm{day} /$ night $(\mathrm{D} / \mathrm{N})$ (Study 1) or $30 / 18{ }^{\circ} \mathrm{C}\left(86.0 / 64.4^{\circ} \mathrm{F}\right) \mathrm{D} / \mathrm{N}$ (Study 2). One-half of all plants in each study were positioned under bottomless shade boxes which reduced

The many important contributions of Brenda Schult, Lee Duncan, Kim Hershberger, and Glen Cassidy are gratefully acknowledged. We thank Peter Ling, Michelle Jones, and Annette Wszelaki for their critical reading of the manuscript and Geza Hrazdina, Cornell University, for supplying cyanidin 3 -glucoside chloride. Manuscript number HCS03-12. Salaries and research support provided in part by State and Federal funds appropriated to the Ohio Agricultural Research and Development Center, The Ohio State University. Work also supported in part by the College of Wooster and with grants from the Ohio Agricultural Research and Development Center and Ohio Vegetable and Small Fruit Research and Development program. Use of trade names does not imply endorsement of the products named nor criticism of similar ones not named.

${ }^{1}$ Department of Horticulture and Crop Science, The Ohio State University, Ohio Agricultural Research and Development Center (OARDC), 1680 Madison Avenue, Wooster, Ohio 44691-4096.

${ }^{2}$ Graduate student, Agricultural Education, Purdue University, West Lafayette, Indiana. Formerly, undergraduate student, College of Wooster, Wooster, Ohio. Work described herein was completed as part of the Independent Study requirement at the College of Wooster.

${ }^{3}$ Corresponding author; e-mail kleinhenz@osu.edu. 
incoming light intensity by $50 \%$. Pigment concentrations were measured in leaf tissue 9, 16, and 23 days after transplanting. Each study was repeated twice. Regardless of temperature regimen, variety influenced all pigment concentrations, while shading affected, primarily, Antho concentrations. ChlA and ChlB concentrations were influenced by growth stage. In Study 1, chlorophyll concentrations were significantly greater in 'Green Vision' than 'New Red Fire' or 'Rolina', but not 'Galactic'. Also, Antho concentrations were significantly greater in 'Galactic' than the other varieties. In Study 2, chlorophyll concentrations were greatest in 'Green Vision', with similar concentrations among the remaining varieties. Antho concentrations were greatest in 'Galactic', intermediate in 'New Red Fire' and 'Rolina', and lowest in 'Green Vision'. Shading significantly reduced Antho concentrations in 'Galactic' and 'Rolina' under both temperature regimens and 'New Red Fire' at $30 / 18^{\circ} \mathrm{C} \mathrm{D} / \mathrm{N}$, but increased Antho concentrations in 'Green Vision'. Chlorophyll concentrations tended to decrease with plant age. Pigment concentration data clarified what was apparent to the unaided eye-namely, that the amount and intensity of green and red color varied among plants subjected to different shading and temperature treatments. Therefore, these data may aid in developing strategies to achieve targeted levels of pigmentation (especially red) in lettuce, an important criterion of crop quality and potential market value.

I ndicators of lettuce quality include color, texture, flavor, and other attributes, many of which may be influenced by abiotic and biotic factors (Kader et al., 1973; Simonne et al., 2002). Color, specifically green as related to chlorophyll and red as related to anthocyanin, is particularly important to lettuce crop quality (Hodges et al., 2000; Ryder, 1999). The amounts and distribution of chlorophyll and anthocyanin in lettuce are strongly influenced by genetics (Lindqvist, 1960a, 1960b, 1960c; Ryder, 1999). However, while anthocyanins are found in nearly all plants at some stage, they are among the least understood of plant metabolites (Chalker-Scott, 1999).

Light and temperature are also thought to impact anthocyanin synthesis (Katz and Weiss, 1999; Moscovici et al., 1996; Shvarts et al., 1997), although knowledge of their influence in lettuce appears to be less advanced than for other crops. Anthocyanin concentrations were affected by light wavelength (Katz and Weiss, 1999; Krizek et al., 1998; Oren-Shamir and Nissim, 1999) in several species. Increases in anthocyanin at lower temperatures have also been reported for apple (Malus $\times$ domestica) and peach (Prunus persica) shoots (Leng et al., 2000) and suspension-cultured strawberry (Fragaria xananassa) (Zhang et al., 1997). Working with petunia (Petunia bybrida), Shvarts et al. (1997) suggested that moderate to low temperatures act as a specific, separate signal in the regulation of gene expression governing anthocyanin biosynthesis. Interestingly, Oren-Shamir and Nissim (1999) reported that low temperatures affected fraser photinia (Photinia $\times$ fraseri) pigmentation only when coupled with ultraviolet light. Additional information regarding the influence of environmental factors on anthocyanin concentrations is available for apple (Arakawa, 1988; Merzlyak and Chivkunova, 2000; Reay and Lancaster, 2001), cabbage (Brassica oleracea Capitata Group) (Hrazdina and Creasy, 1979), grape (Vitis spp.) (Motosugi et al., 1995; RoubelakisAngelakis and Kliewer, 1986), marigold (Tagetes patula) (Armitage and Carlson, 1981), sweet cherry (Prunus avium) (Arakawa, 1993), and other crops. Comparatively less information is available regarding the interaction of genetics, light intensity, and growing temperature on the level of major pigments, including anthocyanins, in lettuce. A better understanding of these factors would assist growers in achieving optimal lettuce leaf coloration. Our objective was to document pigment concentrations at three stages of development in four varieties of lettuce exposed to contrasting light and temperature treatments.

\section{Materials and methods}

Plant Growth, Temperature, AND LIGHT TREATMENT. Seeds of four commercially available varieties of leaf lettuce ['Galactic' (Johnny's Selected Seeds, Winslow, Maine); 'Green Vision', 'New Red Fire', 'Rolina' (Siegers Seed Co., Holland, Mich.)] were planted into 200-cell trays containing Premier Pro-Mix BX (Premier Horticulture, Ltd., Quakertown, Pa.) on 18 July and 22 Nov. 2001 and 15 Jan. 2002 and placed under $30 / 18^{\circ} \mathrm{C}$ day $/$ night $(\mathrm{D} / \mathrm{N})$ temperatures for $30 \mathrm{~d}$ in an environmentally controlled greenhouse room $[7.6 \times 7.6 \mathrm{~m}(25 \mathrm{ft})]$ at the Ohio Agricultural Research and Development Center (OARDC) in Wooster, Ohio. Thereafter, seedlings having two to four true leaves were transplanted into $15.2-\mathrm{cm}$ (6-inch), $1500-\mathrm{mL}(3-\mathrm{pt})$ green plastic pots filled with steam-sterilized rooting medium ( 1 perlite : 1 peat : 1 Wooster silt loam soil, by volume) and subjected to differential temperature and light conditions for $23 \mathrm{~d}$.

On 17 Aug. 2001 and 14 Feb. 2002 , immediately after transplanting, 54 plants of each variety were placed in a greenhouse room maintained at 30 ${ }^{\circ} \mathrm{C}$ D/N (Study 1). Eighteen plants of each variety were placed in a staggered arrangement on each of three benches $[5.5 \times 1.2 \mathrm{~m}(18 \times 4 \mathrm{ft})]$ in the greenhouse room. Bottomless shade boxes $[2.4 \times 1.2 \times 0.9 \mathrm{~m}(8 \times 4 \times 3 \mathrm{ft})]$ were constructed of a single layer of shade cloth $[12 \times 100$, DLT 47\%, 6-No Tarpaulin (K Pro Supply Co., Inc., Sarasota, Fla.)] designed to reduce incoming light intensity $50 \%$ attached to a frame of polyvinyl chloride tubing [ $1.27 \mathrm{~cm}$ outer diameter $(0.5 \mathrm{inch})]$. A shade box containing nine plants of each variety was placed on either the north or south end of each greenhouse room. Based on readings taken by automated sensors within each room, supplemental lighting was provided from twelve 1000-W high pressure sodium vapor lamps (General Electric Lighting, Cleveland, Ohio) to maintain ambient light levels above shade boxes at 250 to $450 \mu \mathrm{mol} \cdot \mathrm{m}^{-2} \cdot \mathrm{s}^{-1}$ (depending on natural light levels) through a 12-h light period. A randomized complete-block design was used in each greenhouse room with each bench comprising a replication containing 18 plants of each variety (nine shaded, nine unshaded).

On 17 Aug. and 22 Nov. 2001, immediately after transplanting, 54 plants of each variety were returned to a greenhouse room maintained at $30 / 18{ }^{\circ} \mathrm{C} \mathrm{D} / \mathrm{N}$ (Study 2). All other growing conditions and factors were as described in Study 1.

In both studies, plants received a total of about $200 \mathrm{~mL}(6.8 \mathrm{fl} \mathrm{oz})$ of distilled water daily via two cycles of drip irrigation. Plants were fertilized weekly using a $200 \mathrm{mg} \cdot \mathrm{L}^{-1}(\mathrm{ppm})$ solution made with Peters 20-20-20 Professional WaterSoluble Fertilizer [20N-8.7P-16.6K (Scotts-Sierra Horticultural Products Co., Marysville, Ohio)] and injected 
into the irrigation line. Plants received about $2.6 \mathrm{mg}(28,350 \mathrm{mg}=1.0 \mathrm{oz})$ of nitrogen, $1.2 \mathrm{mg}$ of phosphorus, and $2.2 \mathrm{mg}$ of potassium each week.

Pigment extraction and measureMENT. Samples were taken from three different shaded and unshaded plants per variety per room at three stages of development $[9,16$, and $23 \mathrm{~d}$ after transplanting (DAT)]. Sample dates corresponded with potential market stages of baby, midhead, and mature lettuce. Samples were collected from different plants at each sampling; however, plants from which tissue was collected remained in place until the study was completed to minimize changes resulting from shifts in plant population and light distribution. Leaf number 2, 6, or 8 from the outside of the whorl was detached at growth stages 1, 2, and 3 , respectively. Detached leaves were folded once along and then across the midrib. Then, a total of $205-\mathrm{mm}(0.2$ inch) disks were removed from within 7 to $10 \mathrm{~mm}$ ( 0.3 to 0.4 inches $)$ of the leaf margin using a cork borer [Boekel Brass Plated Cork Borer (Fisher Scientific, Pittsburgh, Pa.)]. Two groups of 10 randomly selected disks each were placed in separate $1.5-\mathrm{mL}$ graduated microcentrifuge tubes (FisherScientific) held on ice, weighed ( 40 to $120 \mathrm{mg}$ ), and transferred to dark, $-20^{\circ} \mathrm{C}\left(-4.0^{\circ} \mathrm{F}\right)$ storage within $20 \mathrm{~min}$ of collection. Pigment extraction and measurement using accepted protocols began one month after the completion of sampling.

To extract and measure pigments, Eppendorf tubes containing 10 frozen leaf disks were immersed in liquid nitrogen for $10 \mathrm{~s}$. Leaf disks were imme- diately pulverized using a pre-cooled Eppendorf-pestle drill attachment (Gonnet and Fenet, 2000; OrenShamir and Nissim, 1999). $1 \mathrm{~mL}$ of a $1 \%$ hydrochloric acid $(\mathrm{HCl}) /$ methanol $(1: 99 \mathrm{v} / \mathrm{v})$ solution was immediately added to the sample tube which was then mechanically agitated for $2 \mathrm{~s}$. Samples were incubated for $\mathrm{l} \mathrm{h}$ in the dark at $4{ }^{\circ} \mathrm{C}\left(39.2{ }^{\circ} \mathrm{F}\right)$ with occasional agitation (Katz and Weiss, 1999; Krizek et al., 1998; Singh et al., 1999; Voipio and Autio, 1995). After incubation, samples were centrifuged for $10 \mathrm{~min}$ at 2,000 $\mathscr{g}_{\mathrm{n}}[6,000 \mathrm{rpm}$ in a Labnet minicentrifuge (model 1201; Thomas Scientific, Swedesboro, N.J.)] and the liquid fraction decanted, transferred to a clean cuvette [Fisher Brand round cuvettes (Fisher Scientific)], brought to a volume of $8 \mathrm{~mL}$ in a $1 \% \mathrm{HCl} /$ methanol $(1: 99 \mathrm{v} / \mathrm{v})$ solution (Oren-Shamir and Nissim, 1999; Singh et al., 1999), and held on ice until use. Readings of absorbance at $420 \mathrm{~nm}$ [chlorophyll a (ChlA) , $535 \mathrm{~nm}$ [anthocyanin (Antho)], and $650 \mathrm{~nm}$ [chlorophyll b (ChlB)] were taken using a spectrophotometer [model 340 (Sequoia-Turner Corp., Mountain View, Calif.)]. Preliminary tests conducted using tissue from this study (data not shown) indicated that the wavelengths chosen are consistent with those resulting in absorption maxima for the pigments studied here and in previous reports (Adamse, 1989; Singh et al., 1999). Leaf tissue pigment concentrations were calculated using sample absorbance values, tissue weight, and equations from standard curves depicting relationships between known pigment concentrations and absorbance. Standard curves were developed using solutions containing laboratory grade $\mathrm{ChlA}$ and $\mathrm{ChlB}$ (Sigma-Aldrich, St. Louis, Mo.) and cyanidin 3-glucoside chloride provided by Dr. Geza Hrazdina, Cornell University (Keller and Hrazdina, 1998; Hrazdina and Creasy, 1979).

Statistical analysis. Preliminary analysis revealed that treatment effects on pigment concentrations did not differ between replicates in time of Studies 1 and 2 (data not shown). Therefore, data from replicate studies conducted at the same temperature regimen were pooled and subjected to analysis of variance (ANOVA) to test main effects and interactions of variety $(\mathrm{V})$, shading $(\mathrm{S})$, and growth stage (GS) on pigment concentrations within each temperature regimen using Statistical Analysis System version 8e for Windows (SAS Institute, Cary, N.C.). Antho concentrations were significantly affected by the $\mathrm{V} \times \mathrm{S}$ interaction (Table 1). Therefore, Fisher's least significant difference test $(\alpha=0.01)$ was used to compare the effect of S on Antho concentration within each variety. Also, concentrations of ChlB and Antho tended to be significantly affected by the $S \times$ GS interaction (Table 1). Therefore, Fisher's least significant difference test $(\alpha=0.01)$ was used to compare the effect of S on ChlB and Antho concentrations at each growth stage.

\section{Results and discussion}

The results underscore evidence from the literature (Simonne et al., 2002 ) and anecdotal information from commercial lettuce produc-

Table 1. Analysis of variance for the impact of variety, shade treatment, and growth stage on concentrations of chlorophyll a, chlorophyll $\mathrm{b}$ and anthocyanin in leaves of lettuce grown under contrasting temperature regimens in environmentally controlled greenhouse rooms in Wooster, Ohio. Each study was repeated twice (July-September 2001, December 2001-February 2002).

\begin{tabular}{|c|c|c|c|c|c|c|c|}
\hline \multirow[b]{5}{*}{ Source } & \multirow[b]{5}{*}{$\mathbf{d f}^{z}$} & \multirow{2}{*}{\multicolumn{3}{|c|}{$\begin{array}{c}\text { Study } 1 \\
30{ }^{\circ} \mathrm{C}\left(86.0{ }^{\circ} \mathrm{F}\right. \\
\text { day } / \text { night }\end{array}$}} & \multicolumn{3}{|c|}{ Study 2} \\
\hline & & & & & \multicolumn{3}{|c|}{$\begin{array}{c}30 / 18^{\circ} \mathrm{C}\left(86.0 / 64.4^{\circ} \mathrm{F}\right) \\
\text { day/night }\end{array}$} \\
\hline & & \multicolumn{6}{|c|}{ Pigment } \\
\hline & & \multicolumn{2}{|c|}{ Chlorophyll } & \multirow[b]{2}{*}{ Anthocyanin } & \multicolumn{2}{|c|}{ Chlorophyll } & \multirow[b]{2}{*}{ Anthocyanin } \\
\hline & & a & b & & a & b & \\
\hline Variety $(\mathrm{V})^{\mathrm{y}}$ & 3 & ** & $* * *$ & $* * *$ & * & ** & $* * *$ \\
\hline $\mathrm{V} \times \mathrm{S}$ & 3 & NS & NS & $* * *$ & NS & NS & $* * *$ \\
\hline $\mathrm{V} \times \mathrm{GS}$ & 6 & * & NS & NS & NS & NS & NS \\
\hline $\mathrm{S} \times \mathrm{GS}$ & 2 & * & $\star *$ & NS & NS & NS & ** \\
\hline $\mathrm{V} \times \mathrm{S} \times \mathrm{GS}$ & 6 & NS & NS & NS & NS & NS & NS \\
\hline
\end{tabular}

df $=$ degrees of freedom

'Varieties are 'Galactic', 'Green Vision', 'New Red Fire', and 'Rolina'.

'Shading levels are none and $50 \%$ ambient.

"Growth stages are 9,16 , and $23 \mathrm{~d}$ after transplanting.

Ns, $,{ }^{* * *}, * * *$ Nonsignificant or significant at $P \leq 0.05,0.01$, or 0.001 , respectively, for each variable. 
ers that pigmentation in lettuce and other crops, particularly that related to red color, is influenced by genetic and environmental variables, acting alone or in combination.

Compared to most interactions, the main effects of variety, shading and growth stage acted more strongly in influencing pigment concentrations in this study. An exception to this observation, the $\mathrm{V} \times \mathrm{S}$ interaction for Antho, was significant in both studies (temperature regimens) and, of the six interactions found to be significant (Table 1), perhaps the most compelling. Shading reduced Antho concentrations $48 \%$ to $59 \%$ in 'Galactic', 'Rolina', and 'New Red Fire' (depending on temperature) but, curiously, tended to increase Antho concentrations $24 \%$ to $38 \%$ in 'Green Vision' (Fig. 1). These results are consistent with those of Voipio and Autio (1995) who reported that anthocyanin concentrations in 'Red Salad Bowl', 'New Red Fire' and 'Sesam' lettuce were increased by exposure to high light intensity. They are also consistent with other reports (Voipio,
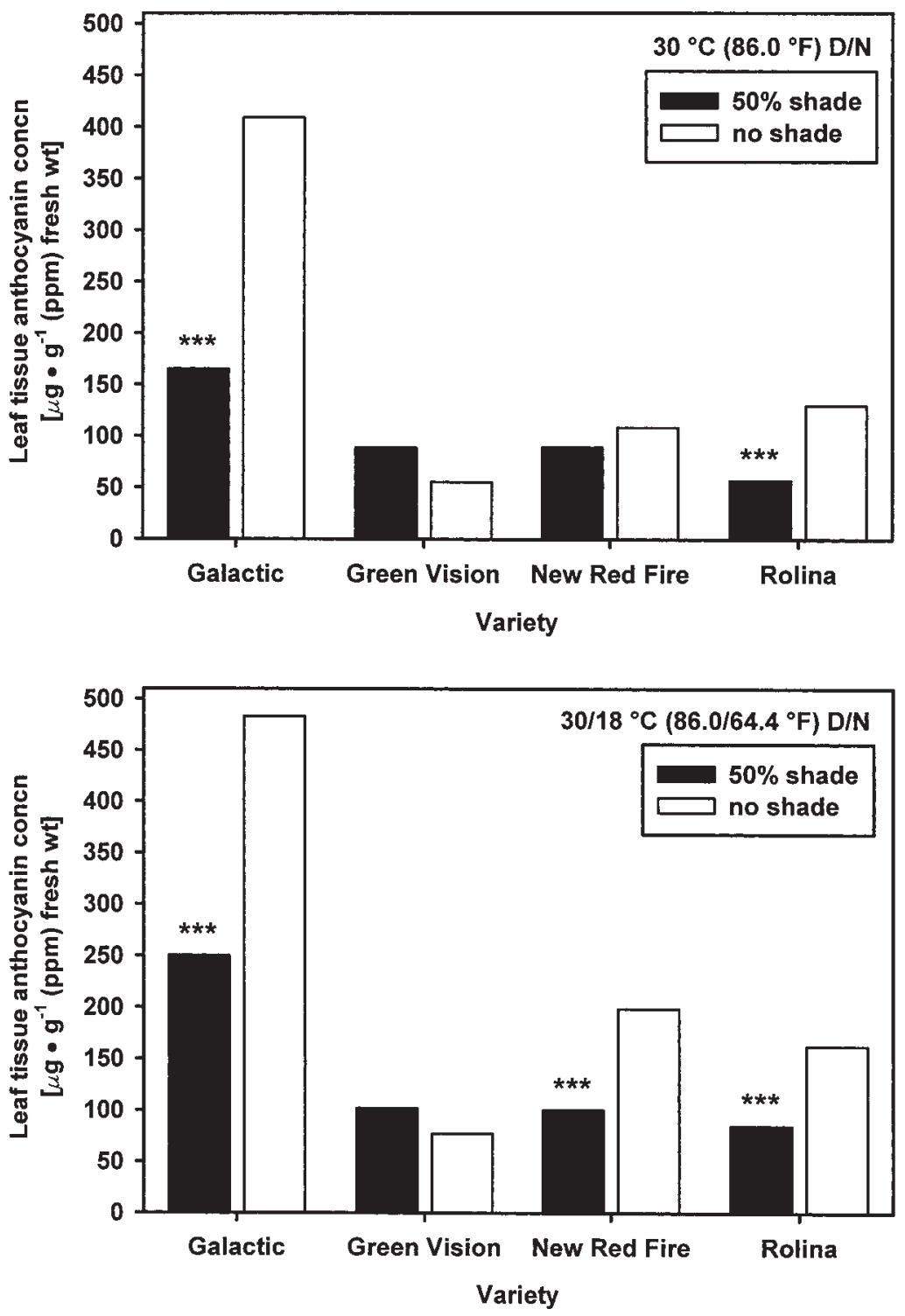

Fig. 1. Effect of shading on the anthocyanin concentration in leaf tissue of four varieties ('Galactic', 'Green Vision', 'New Red Fire', and 'Rolina') of greenhouse-grown lettuce. Leaf tissue was collected 9, 16, and $23 \mathrm{~d}$ after transplanting and growth under $30{ }^{\circ} \mathrm{C}\left(86.0^{\circ} \mathrm{F}\right)$ day/night $(\mathrm{D} / \mathrm{N})($ top $)$ or $30 / 18^{\circ} \mathrm{C}\left(86.0 / 64.4^{\circ} \mathrm{F}\right) \mathrm{D} / \mathrm{N}$ (bottom) and either $50 \%$ shade (50\% ambient light intensity) or no shade. Asterisks $(* * *)$ indicate that shading significantly affected anthocyanin concentrations in the varieties shown according to Fisher's least significant difference test $(\alpha=0.01)$. Values shown are the mean of $\mathbf{5 4}$ observations per variety per shade treatment and represent the mean of all samples collected 9, 16, and $23 \mathrm{~d}$ after transplanting.
1992; Voipio and Autio, 1991) and commercial experience in which some red-leaved varieties appeared to be more prone to natural low light intensity-induced bleaching of red color during greenhouse lettuce production in Ohio (L. Smucker, personal communication) and elsewhere. Finally, shading-induced reductions in Antho concentration in this study led shaded plants of red-leaved varieties to be less intense in color (Fig. 2), in contrast to the effect noted for 'Green Vision'. Therefore, shading effects on Antho concentrations appear to be driven by the variety or genotype involved.

Though significant, $\mathrm{V} \times \mathrm{GS}$ and $\mathrm{S}$ $\times$ GS interactions (Figs. 3 and 4 ) were minor relative to variety, shading or growth stage main effects (Table 1). On average, ChlA concentrations at 9 DAT exceeded ChlA concentrations at 23 DAT by $24 \%$ in plants grown at 30 ${ }^{\circ} \mathrm{C} \mathrm{D} / \mathrm{N}$ (Table 2). Also, ChlB concentrations at 9 DAT exceeded ChlB concentrations at 23 DAT by $32 \%$ in plants grown at $30 / 18{ }^{\circ} \mathrm{C} \mathrm{D} / \mathrm{N}$. Interestingly, Antho concentrations were unaffected by growth stage, regardless of study (Table 2 ). For commercial and some scientific systems, these trends may be more important than the potential changes in pigment concentration with age in specific varieties. Likewise, the absolute effect of growth stage on ChlA and ChlB in plants grown in Study 1 depended on shade treatment, although it is clear that ChlA and ChlB concentrations were lowest at $23 \mathrm{DAT}$, regardless of shade treatment (Fig. 4). Just as important, shading did not influence ChlA or ChlB concentrations in either temperature regimen (Table 2 ), again, pointing more directly to the main effects of variety and growth stage.

Quantitative data for pigment concentrations clarified what was apparent to the unaided eye-namely, that the relative amounts of green and red color varied among the lettuce varieties studied. The four commercial varieties used in this study represented a range of leaf coloration from uniformly green ('Green Vision') to uniformly red ('Galactic'). Similarly, pigment concentrations (especially Antho) varied among varieties (Table 2 ). In Study 1, ChlA and ChlB concentrations were significantly greater in 'Green Vision' than 'New Red Fire' or 'Rolina' but not 'Galactic' (Table 2 ). Among plants grown at 30/18 


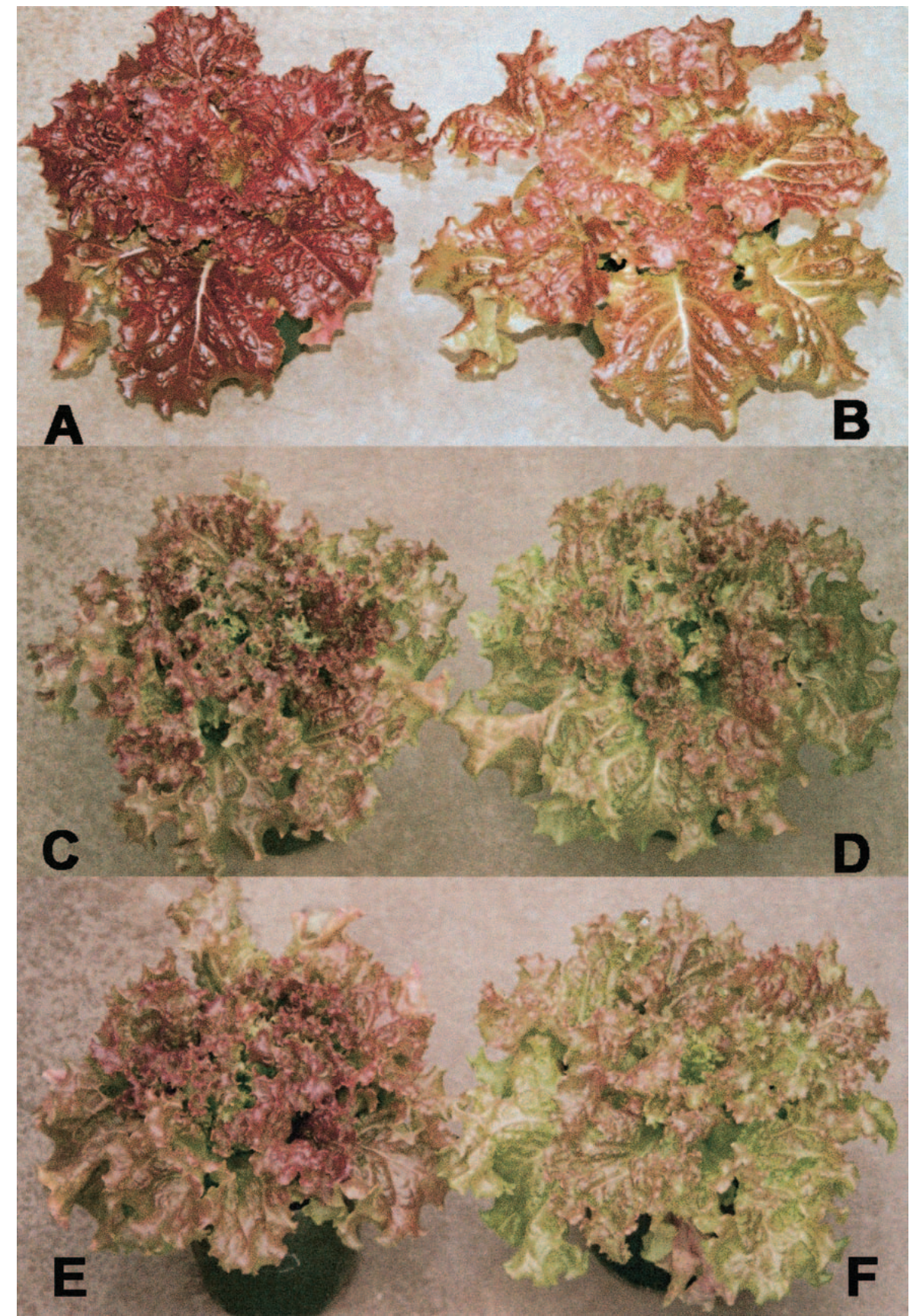

Fig. 2. Effect of shading on the intensity of color at $23 \mathrm{~d}$ after transplanting in three varieties of lettuce grown at $\mathbf{3 0}$ ${ }^{\circ} \mathrm{C}\left(86.0{ }^{\circ} \mathrm{F}\right) \mathrm{day} / \mathrm{night}$ and either $50 \%$ shade (50\% ambient light intensity) or no shade in environmentally controlled greenhouse rooms. (A, C, and $\mathrm{E}$ ),

'Galactic', 'Rolina', 'New Red Fire', respectively, no shading. (B, D, and F), 'Galactic', 'Rolina', 'New Red Fire', respectively, light intensity $\mathbf{5 0 \%}$ ambient. Images collected February 2002.

${ }^{\circ} \mathrm{C}$, concentrations of ChlA and ChlB were highest in 'Green Vision', with similar concentrations among the remaining varieties. 'Galactic' possessed the highest concentrations of Antho in both studies. However, it is interesting to note that 'Galactic' also had relatively high concentrations of ChlA at both temperatures and ChlB at $30{ }^{\circ} \mathrm{C} \mathrm{D} / \mathrm{N}$ while Antho concentrations were lowest in 'Green Vision' at both temperatures. In fact, in general, relatively fewer differences were found among varieties in ChlA and ChlB than for Antho. This is consistent with the status of anthocyanins as secondary pigments (Harborne, 1992).

Although temperature effects on pigment concentrations were not directly studied here, interesting and consistent trends were observed, with results similar to other reports (Leng et al., 2000; Shvarts et al., 1997; Zhang et al., 1997) of low temperature-induced increases in anthocyanin concentration. Concentrations of all pigments were lower in plants of Study 1 than in plants of Study 2, regardless of variety, shade treatment or growth stage (Table 2). Mean concentrations of ChlA, ChlB, and Antho were $24 \%$ to $31 \%$ lower in plants grown at $30^{\circ} \mathrm{C} \mathrm{D} / \mathrm{N}$ compared to $30 / 18{ }^{\circ} \mathrm{C} \mathrm{D} / \mathrm{N}$. Interestingly, the mean and range of pigment concen-

Fig. 3 (right). Effect of variety and growth stage on chlorophyll a concentrations in leaf tissue of four varieties ('Galactic', 'Green Vision', 'New Red Fire', and 'Rolina') of greenhousegrown lettuce. Leaf tissue was collected 9,16 , and $23 \mathrm{~d}$ after transplanting (DAT) and growth under $30^{\circ} \mathrm{C}(86.0$ $\left.{ }^{\circ} \mathrm{F}\right)$ day/night and either $50 \%$ shade (50\% ambient light intensity) or no shade. Bars within the same variety and topped by the same letter are not significantly different according to Fisher's least significant difference test $(\alpha=0.01)$. Values shown are the mean of 36 observations per variety per growth stage and represent the mean of all samples collected from shaded and unshaded plants.

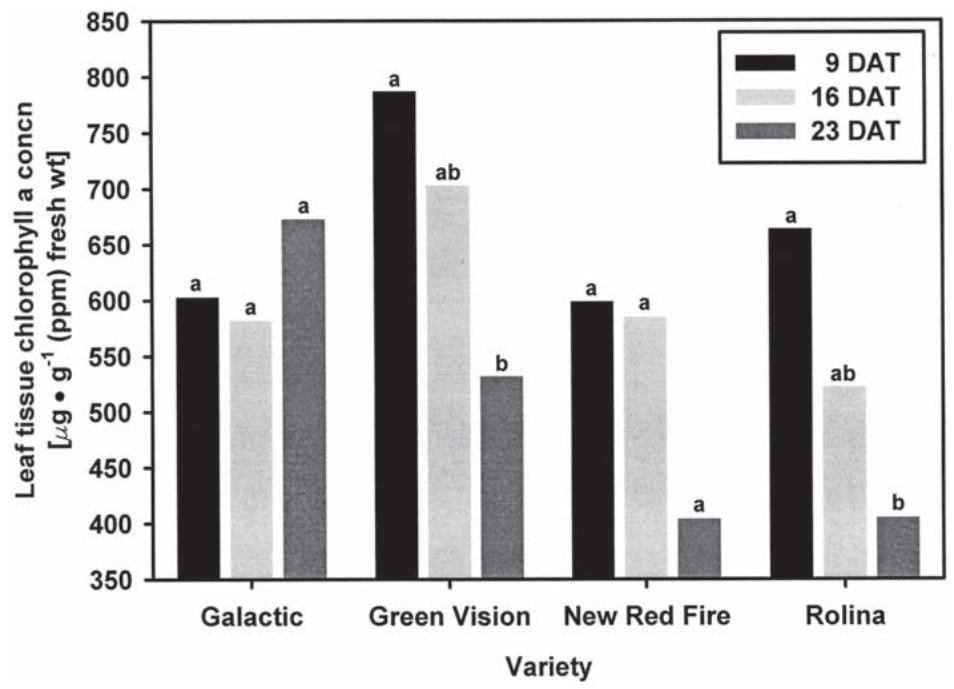

Variety 


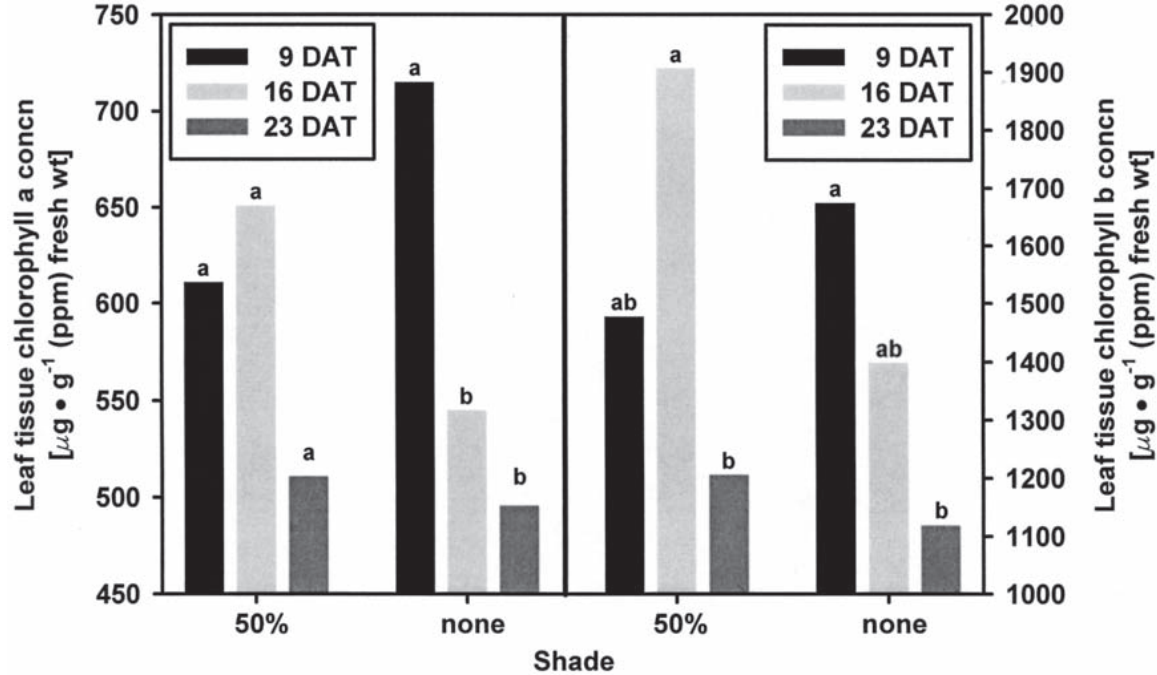

Fig. 4. Effect of shading and growth stage on chlorophyll a (left) and chlorophyll b (right) concentrations in leaf tissue of four varieties ('Galactic', 'Green Vision', 'New Red Fire', and 'Rolina') of greenhouse-grown lettuce. Leaf tissue was collected 9, 16, and $23 \mathrm{~d}$ after transplanting (DAT) and growth under $30^{\circ} \mathrm{C}\left(86.0{ }^{\circ} \mathrm{F}\right) \mathrm{day} /$ night and either $50 \%$ shade $(50 \%$ ambient light intensity) or no shade. Bars within the same shade treatment and topped by the same letter are not significantly different according to Fisher's least significant difference test $(\alpha=0.01)$. Values shown are the mean of 72 observations and represent the mean of all varieties at each growth stage.

trations within and among varieties differed with study. For example, the mean ChlA concentration in 'Green Vision' and Antho concentrations in 'Galactic' were 32\% and 22\% greater in Study 2 than in Study 1, respectively (Table 2). Likewise, the range of pigment concentration among the four varieties was $22 \%$ to $33 \%$ greater in Study 1 than in Study 2.

Additional verification of effects reported here would benefit small-moderate scale greenhouse lettuce production in temperate regions prone to periods of low light and temperatures during growth. Additional data would assist in identifying genotype-management combinations or selecting between investments in light or temperature regulation equipment in order to achieve target levels of red coloration, an important criterion of lettuce crop and product quality. In this regard, reports on the genetic control of red pigmentation in lettuce (Ryder, 1999; Simonne et al., 2002) help describe the separate and combined effects of genetics and environment on pigment concentrations in lettuce more completely. Likewise, ongoing studies by this group and its cooperators employ a unique collection of strongly-related, red-colored genotypes varying primarily in genes thought to influence anthocyanin production. These genotypes have also been used in studies exploring the effect of greenhouse films and other factors on anthocyanin concentrations (Benoit, 1997; Benoit and Ceustermans, 1997; Benoit and Ceustermans, 1999).

\section{Literature cited}

Adamse, P., J.L. Peters, P.A.P.M. Jaspers, A. van Tuinen, and R.E. Kendrick. 1989. Photocontrol of anthocyanin synthesis in tomato seedlings: A genetic approach. Photochem. Photobiol. 50:107-111.

Arakawa, O. 1988. Photoregulation of anthocyanin synthesis in apple fruit under UV-B and red light. Plant Cell Physiol. 29: 1385-1389.

Table 2. Impact of variety, shade treatment, and growth stage on concentrations of chlorophyll a, chlorophyll b, and anthocyanin in leaves of lettuce grown under contrasting temperature regimens in environmentally controlled greenhouse rooms in Wooster, Ohio. Each study was repeated twice (July-September 2001, December 2001-February 2002 ).

\begin{tabular}{|c|c|c|c|c|c|c|c|}
\hline \multirow[b]{5}{*}{ Source } & \multirow[b]{5}{*}{$\mathbf{n}^{\mathrm{z}}$} & \multirow{2}{*}{\multicolumn{3}{|c|}{$\begin{array}{c}\text { Study } 1 \\
30{ }^{\circ} \mathrm{C}\left(86.0{ }^{\circ} \mathrm{F}\right) \\
\text { day/night }\end{array}$}} & \multicolumn{3}{|c|}{ Study 2} \\
\hline & & & & & \multicolumn{3}{|c|}{$\begin{array}{c}30 / 18^{\circ} \mathrm{C}\left(86.0 / 64.4^{\circ} \mathrm{F}\right) \\
\mathrm{day} / \mathrm{night}\end{array}$} \\
\hline & & \multicolumn{6}{|c|}{ Leaf tissue pigment concn $\left[\mu \mathrm{g} \cdot \mathrm{g}^{-1}(\mathrm{ppm})\right.$ fresh $\left.\mathrm{wt}\right]$} \\
\hline & & \multicolumn{2}{|c|}{ Chlorophyll } & \multirow[b]{2}{*}{ Anthocyanin } & \multicolumn{2}{|c|}{ Chlorophyll } & \multirow[b]{2}{*}{ Anthocyanin } \\
\hline & & a & $\mathbf{b}$ & & a & $\mathbf{b}$ & \\
\hline \multicolumn{8}{|l|}{ Variety } \\
\hline Galactic & 36 & $619 \mathrm{ab}^{y}$ & $1493 \mathrm{ab}$ & $287 \mathrm{a}$ & $864 \mathrm{ab}$ & $2033 b$ & $367 \mathrm{a}$ \\
\hline Green Vision & 36 & $674 \mathrm{a}$ & $1780 \mathrm{a}$ & $72 \mathrm{~b}$ & 986 a & $2555 \mathrm{a}$ & $90 \mathrm{c}$ \\
\hline New Red Fire & 36 & $529 \mathrm{~b}$ & $1289 \mathrm{~b}$ & $99 \mathrm{~b}$ & $808 \mathrm{ab}$ & $1927 \mathrm{~b}$ & $150 \mathrm{~b}$ \\
\hline Rolina & 36 & $530 \mathrm{~b}$ & $1292 \mathrm{~b}$ & $93 \mathrm{~b}$ & $769 \mathrm{~b}$ & $1934 \mathrm{~b}$ & $124 \mathrm{bc}$ \\
\hline $\mathrm{LSD}_{0.01}$ & & 119 & 318 & 49 & 194 & 518 & 47 \\
\hline \multicolumn{8}{|l|}{ Shading } \\
\hline None & 114 & $585 \mathrm{a}$ & $1397 \mathrm{a}$ & $176 \mathrm{a}$ & $796 \mathrm{a}$ & $1937 \mathrm{a}$ & $231 \mathrm{a}$ \\
\hline $50 \%$ & 114 & $591 \mathrm{a}$ & $1530 \mathrm{a}$ & $100 \mathrm{~b}$ & $917 \mathrm{a}$ & $2287 \mathrm{a}$ & $134 \mathrm{~b}$ \\
\hline $\mathrm{LSD}_{0.01}$ & & 84 & 225 & 34 & 137 & 367 & 34 \\
\hline \multicolumn{8}{|l|}{ Growth stage } \\
\hline 9 DAT $^{x}$ & 48 & $663 a$ & $1575 \mathrm{a}$ & $140 \mathrm{a}$ & $1037 \mathrm{a}$ & $2472 \mathrm{a}$ & $173 \mathrm{a}$ \\
\hline $16 \mathrm{DAT}$ & 48 & $598 \mathrm{ab}$ & $1654 \mathrm{a}$ & $146 \mathrm{a}$ & $813 \mathrm{~b}$ & $2192 \mathrm{a}$ & $171 \mathrm{a}$ \\
\hline $23 \mathrm{DAT}$ & 48 & $504 \mathrm{~b}$ & $1162 \mathrm{~b}$ & $127 \mathrm{a}$ & $719 \mathrm{~b}$ & $1672 \mathrm{~b}$ & $204 a$ \\
\hline $\mathrm{LSD}_{0.01}$ & & 103 & 276 & 42 & 168 & 449 & 41 \\
\hline
\end{tabular}

${ }^{\mathrm{z}} \mathrm{n}=$ number of data points used in statistical analysis of individual main effects.

${ }^{y}$ Numbers in the same column and main effect and followed by the same letter are not significantly different according to Fisher's least significant difference test at $\alpha=0.01$ (LSD ${ }_{0.01}$ ).

${ }^{x} \mathrm{DAT}=$ days after transplanting. 
Arakawa, O. 1993. Effect of ultraviolet light on anthocyanin synthesis in lightcolored sweet cherry, cv. Sato Nishiki. J. Jpn. Soc. Hort. Sci. 62:543-546.

Armitage, A.M. and W.H. Carlson. 1981. The effect of quantum flux density, day and night temperature and phosphorus and potassium status on anthocyanin and chlorophyll content in marigold leaves. J. Amer. Soc. Hort. Sci. 106:639-642.

Benoit, F. 1997. Modern plastic films and their possibilities. Proeftuinnieuws $7: 18-19$

Benoit, F. and N. Ceustermans. 1997. Effect of a photoselective greenhouse film on a few vegetable crops in the Belgian North Sea climate. Comite Intl. des Plastiques en Agr. (CIPA) Proc. 21:81-92.

Benoit, F. and N. Ceustermans. 1999. Effect of cooling the nutrient solution, lighting and ethrel spraying on purple colouring in NFT-Lollo Rossa Lettuce. Acta Hort. 481:327-330.

Chalker-Scott, L. 1999. Environmental significance of anthocyanins in plant stress responses. Photochemistry Photobiology 70:1-9.

Gonnet, J.F. and B. Fenet. 2000. "Cyclamen red" colors based on a macrocyclic anthocyanin in carnation flowers. J. Agr. Food Chem. 48:22-26.

Harborne, J.B. 1992. Flavonoid pigments, p. 389-427. In: G.A. Rosenthal, and M.R. Berenbaum (eds.). Herbivores: Their interaction with secondary plant metabolites. vol 1. The chemical participants. Academic Press, New York.

Hodges, D.M., C.F. Forney, and W. Wismer. 2000. Processing line effects on storage attributes of fresh-cut spinach leaves. HortScience 35:108-1311.

Hrazdina, G. and L.L. Creasy. 1979. Light induced changes in anthocyanin concentration, activity of phenylalanine ammonia-lyase and flavanone synthase and some of their properties in Brassica oleracea red cabbage. Phytochemistry 18:581-584.
Kader, A.A., W.J. Lipton, and L.L. Morris. 1973. Systems for scoring quality of harvested lettuce. HortScience 8:408-409.

Katz, A. and D. Weiss. 1999. Light regulation of anthocyanin accumulation and chalcone synthase gene expression in Petunia flowers. Israel J. Plant Sci. 47:225-229.

Keller, M. and G. Hrazdina. 1998. Interaction of nitrogen availability during bloom and light intensity during veraison. II. Effects on anthocyanin and phenolic development during grape ripening. Amer. J. Enol. Viticult. 49:341-349.

Krizek, D.T., S.J. Britz, and R.M. Mirecki. 1998. Inhibitory effects of ambient levels of solar UV-A and UV-B radiation on growth of cv. New Red Fire lettuce. Physiol. Plantarum 103:1-7.

Leng, P., H. Itamura, H. Yamamura, and X.M. Xeng. 2000. Anthocyanin accumulation in apple and peach shoots during cold acclimation. Sci. Hort. 83:43-50.

Lindqvist, K. 1960a. Cytogenetic studies in serriola group of Lactuca. Hereditas $46: 75-151$

Lindqvist, K. 1960b. On the origin of cultivated lettuce. Hereditas 46:319-350.

Lindqvist, K. 1960c. Inheritance studies in lettuce. Hereditas 46:387-470.

Merzlyak, M.N. and O.B. Chivkunova. 2000. Light stress induced pigment changes and evidence for anthocyanin photo protection in apples. J. Phytochem. Phytobiol. 55:155-163.

Moscovici, S., D. Moalem-Beno, and D. Weiss. 1996. Leaf-mediated light responses in petunia flowers. Plant Physiol. 110: 1275-1282.

Motosugi, H., K. Beppu, and A. Sugiura. 1995. Studies on NFT culture of 'Kyoho' grapes: Water stress symptoms and fruit quality of grapevines supplied ammonium nitrogen at low $\mathrm{pH}$ after veraison. Acta Hort. 396:227-234.

Oren-Shamir, M. and A. Levi-Nissim. 1999. Temperature and gibberellin effect on growth and anthocyanin pigmentation in Photinia leaves. J. Hort. Sci. Biotechnol. 74:355-360

Reay, P.F. and J.E. Lancaster. 2001. Accumulation of anthocyanins and quercetin glycosides in 'Gala' and 'Royal Gala' apple fruit skin with UV-B visible irradiation: modifying effects of fruit maturity, fruit size and temperature. Sci. Hort. 90:57-68.

Roubelakis-Angelakis, K.A. and W.M. Kliewer. 1986. Effects of exogenous factors on phenylalanine ammonia-lyase activity and accumulation of anthocyanins and total phenolics in grape berries. Amer. J. Enol. Viticult. 37:275-280.

Ryder, E.J. 1999. Lettuce, endive and chicory. CAB Intl. Publ., New York.

Shvarts, M., A. Borochov, and D. Weiss, 1997. Low temperature enhances petunia flower pigmentation and induces chalcone synthase gene expression. Physiol. Plantarum 99:67-72.

Simonne, A., E. Simonne, R. Eitenmiller, and C. Harris Coker. 2002. Bitterness and composition of lettuce varieties grown in the southeastern United States. HortTechnology 12:721-726.

Singh, A., M.T. Selvi, and R. Sharma. 1999. Sunlight-induced anthocyanin pigmentation in maize vegetative tissues. J. Expt. Bot. 50:1619-1625.

Voipio, I. 1992. Red leaved lettuce cultivars under comparison (in Finnish). Puutarha 95:294-297.

Voipio, I. and J. Autio. 1991. Effects of the intensity and quality of supplementary light on growth and composition of leaf lettuce (in Finnish), p. 19-41. In: The utilization of supplementary light in cultivation of leaf lettuce and in forcing flowering perennials. Univ. Helsinki Publ. 21.

Voipio, I. and J. Autio. 1995. Responses of red-leaved lettuce to light intensity, UV-A radiation and root zone temperature. Acta Hort. 399:183-187.

Zhang, W., M. Seki, and S. Furusaki. 1997. Effect of temperature and its shift on growth and anthocyanin production in suspension cultures of strawberry cells. Plant Sci. 127: 207-214. 